\title{
The Process of Postagrogenic Lands Overgrowing within the National Parks of North-West Russia
}

\author{
Sergey Tretyakov* and Sergey Koptev \\ Department of Silveculture and Forest Management, North Arctic Federal University, Russia
}

Submission: March 29, 2018; Published: April 23, 2018

"Corresponding author: Sergey Tretyakov, Department of Silveculture and Forest Management, North Arctic Federal University, Russia, Email: s.v.tretyakov@narfu.ru

\section{Mini Review}

The socio-economic crisis of the $20^{\text {th }}$ century in Russia led to a massive reduction in agricultural land. This is mainly arable land and hayfields. In General, about 40 million hectares of arable land were withdrawn from turnover in Russia during the crisis period. In the North-West of Russia, currently the area of cultivated land is about $30 \%$ of all registered cultivated land [1]. The bulk of the abandoned land is located in the southern part of the region, where agricultural production was the most developed former time. These lands undergo process of transformation mainly under influence of spontaneous overgrowth by the wood both valuable coniferous breeds (a pine, a fir-tree), and deciduous (a birch, an aspen, an alder, willow).

The solution of the issues of rational use of abandoned lands (for example, forest cultivation or maintenance of agricultural landscapes) is very important for national parks and other protected areas created in the region to preserve the unique natural complexes, cultural features and traditions of the local population.

Processes of reforestation, subsequent development and growth of forest stands on the former agricultural lands differ from processes of reforestation on lands with natural formation.

In the territory of the Kenozersky national Park (Arkhangelsk region, Russia) arable and haymaking lands which use was economically unprofitable were predominantly taken out of use. This-small-scale sites were remote from settlements. In connection with the outflow of the population from rural areas around the villages also began to form plots of abandoned land, which began to overgrow by woody-shrub vegetation.

The development of tourism is very important for national parks. Tourists can be attracted by beautiful landscapes that have historically been around settlements. Significant investments are required to maintain all agricultural landscapes in historical form. The main task of the research of overgrowth of postagrogenic lands is to identify those areas that, with minimal timely investments, will create the maximum effect of the presence of historical agro-cultural landscapes.

The rate of fields overgrowth depends on their area, as the process of forest formation begins from the nearest natural stands. It will take 8-10 years to overgrow a field or hayfields up to 5-10 hectares to the degree of forest covered statute [13]. This is the most historically characteristic size of fields and hayfields for the Kenozero national Park. At the same time, the canopy of the forming stand will reduce the height as it moves away from the "wall" of the forest. Predominant tree species in the early stages of overgrowth are alder, willow and birch. Pine appears in small groups. Alder prefers rich and moist loamy soils, pine and birch prevails on sandy loam soils. Alder and willow reach a height of 7-8m in 7 years with an average diameter of $6 \mathrm{~cm}$ at the root level. Spruce and pine for this period reach a height of $0.8-1.0 \mathrm{~m}$. At this age comes the closed canopy stand. To maintain and preserve the open landscapes needed to be more early intervention of forestry measures.

When using postagrogenic lands for the purpose of highquality wood cultivation, it is possible to obtain highly productive coniferous stands that grow on 1-3 class of bonity higher than the stands that are formed on forest soils. So the average height of a pine or spruce stands at the maturity age can make up to $26 \mathrm{~m}$, the stock of a forest stand can reach $400 \mathrm{~m}^{3} /$ ha and this is a very good parameter for the North-West of Russia.

\section{References}

1. Tretyakov SV, Koptev SV, Neverov NA, Novikova NS (2014) Conservation and sustainable management of agricultural landscapes in the Kargopol sector of Kenozero national Park. Vestnik of North (Arctic) Federal University, Series Natural Sciences, Arkhangelsk, pp. 40-47.

2. Tretyakov SV, Koptev SV, Morozov VV, Novikova NS (2016) Preservation and sustainable management of cultural landscapes of the Pochozer cultural landscape complex of the Plesetsk sector of the Kenozero national Park. Arkhangelsk, pp. 303-312.

3. Golubeva LV, Nakvasina EN (2018) Postagrogenic transformation of land in the carbonate sediments. NARFU, Arkhangelsk, p. 152. 


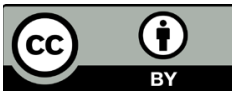

This work is licensed under Creative Commons Attribution 4.0 License

DOI: 10.19080/ARTOAJ.2018.15.555959
Your next submission with Juniper Publishers will reach you the below assets

- Quality Editorial service

- Swift Peer Review

- Reprints availability

- E-prints Service

- Manuscript Podcast for convenient understanding

- Global attainment for your research

- Manuscript accessibility in different formats

( Pdf, E-pub, Full Text, Audio)

- Unceasing customer service

Track the below URL for one-step submission https://juniperpublishers.com/online-submission.php 